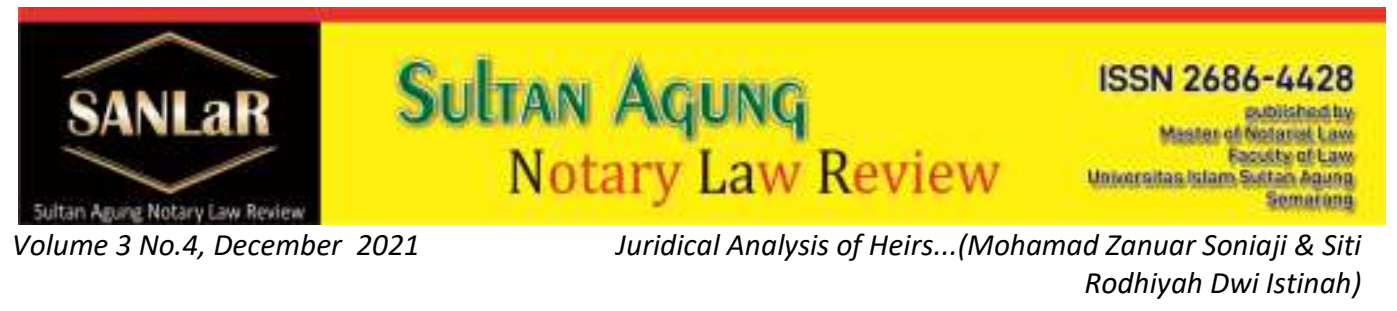

\title{
Juridical Analysis of Heirs Negligence of a Notary in Submission of a Notary Protocol who Dies
}

\author{
Mohamad Zanuar Soniaji*) and Siti Rodhiyah Dwi Istinah ${ }^{* *}$ \\ ${ }^{*}$ Faculty of Law, Universitas Islam Sultan Agung (UNISSULA) Semarang, E-mail: \\ sonieajie6@gmail.com \\ ${ }^{* *}$ Faculty of Law, Universitas Islam Sultan Agung (UNISSULA) Semarang, E-mail: \\ rodhiyah@unissula.ac.id
}

Abstract. The author in this paper takes the title above because he wants to know about the negligence of the Notary's heirs in the delivery of the Notary's protocol that has died, how is the responsibility of the heirs in the submission of the Notary's protocol that has died and is there legal protection for the community if the Notary protocol has not been submitted to another Notary or the recipient of the Notary protocol. This study uses a normative juridical approach and the data used are primary and secondary data obtained through interviews and literature study, data analysis is descriptive analytic. The responsibility of the heirs in the submission of the protocol of a notary who dies is to notify the notary's death to the Notary Supervisory Council (MPD) no later than 7 (seven) working days, and submit the protocol of the notary to another notary or the Regional Supervisory Council (MPD). The responsibility of the heirs is not related to the contents of the deed made by the notary, the responsibility for the deed of a notary who dies cannot be passed on to his heirs or to the notary who holds the notary protocol. Legal protection for the public if the Notary protocol has not been submitted to another Notary or the recipient of the Notary protocol, namely the Notary Protocol as a state archive if it is not immediately submitted to the competent authority, namely the Regional Supervisory Council or the Notary appointed as the Protocol Recipient exceeding the period determined by law, feared that it could be damaged, or even lost. Taking the Notary protocol that has not been handed over to the heirs is a form of legal protection to the community. The purpose of storing this Notary protocol is also a form of legal protection to the public. Notary protocol storage as a vital archive and must be stored and maintained properly as an anticipatory measure for conflicts by the parties in the future.

Keywords: Die; Heir; Notary; Protocol; Public. 


\section{Introduction}

In the ancient of Roman era, there was a group of students who worked as "Scribae" who had the task of taking notes and minutes of various records of activities or decisions that were kept and copies issued, both private and public. This position arose because of the needs of the community at that time which in the development of the times, the position was also called a "Notary". ${ }^{1}$ If the Notary has died, then the heirs of the husband or wife, blood relatives in a straight line of marriage are obligated to notify the Regional Supervisory Council, the notification is no later than 7 (seven) working days, the obligation of the Notary's heirs dies in addition to notifying the Regional Supervisory Council ${ }^{2}$, then the heirs are obliged to submit a Notary protocol. The Notary Protocol must be submitted no later than 30 (thirty) days with the preparation of the minutes of the Notary protocol submission signed by the person submitting and receiving the Notary protocol. ${ }^{3}$

The protocol must be maintained and kept properly by the Notary concerned or by the Notary holding the protocol, and will remain in effect as long as the Notary's position is still required by the state. ${ }^{4}$ The Notary Protocol regulated in the Law on Notary Positions is a very important state archive, which must be maintained and guarded by a Notary because it is a valid and strong evidence if in the future there is a problem between the parties in a deed. ${ }^{5}$ Regarding the Notary protocol in the event that a Notary dies, it has been regulated in UUJN and UUJN Amendments to Article 63 paragraph (2), namely: Protocol Notary is carried out by the heirs of the Notary to another Notary appointed by the Regional Supervisory Council.

The position of the notary deed is the value of an evidence that cannot be claimed for compensation in any form. Claims to A notary will arise where there is a causal relationship between negligence or violations and losses suffered by the parties as well as the existence of a Notary who related to errors or omissions that can be held accountable to him. ${ }^{6}$

\footnotetext{
${ }^{1}$ G.H.S Lumban Tobing, (1999), Peraturan Jabatan Notaris, Jakarta : Erlangga, p. 21

2 Ong Argo Victoria, Ade Riusma Ariyana, Devina Arifani. (2020). Code of Ethics and Position of Notary in Indonesia. Sultan Agung Notary Law Review 2 (4), 397-407, http://lppmunissula.com/jurnal.unissula.ac.id/index.php/SANLaR/article/view/13536

${ }^{3}$ Budiono, Herlien, (2013), Dasar Teknik Pembuatan Akta Notaris, Bandung : Citra Aditya Bakti, p.14.

${ }^{4}$ Habib Adjie, (2014), Hukum Notaris Indonesia Tafsir Telematik Terhadap UU No 30 Tahun 2004 Tentang Jabatan Notaris, Surabaya : Refika Aditama, p. 49

${ }^{5}$ Soegondo Notodisoerjo, (1993), Hukum Notariat di Indonesia Suatu Penjelasan, Second Edition, Jakarta: Raja Grafindo, p. 98

${ }^{6}$ Habib Adjie, (2009), Sanksi Perdata dan Administratif terhadap Notaris sebagai Pejabat Publik, Bandung: Refika Aditama, p. 68
} 
The Temporary Notary Official who will receive the Notary Protocol who has died is a Notary appointed/ratified by the Regional Supervisory Council (MPD) based on Article 70 of the UUJN. The submission of the protocol is carried out no later than 30 (thirty) days with the preparation of an official report on the submission of the Notary protocol signed by the person who submitted and received the Notary Protocol as referred to in Article 63 paragraph (1) of the UUJN. ${ }^{7}$ The Notary Protocol held by the Notary who has died is then handed over to the Notary Temporary Official by the Notary's heirs. The Notary Temporary Official then submits the Notary Protocol to the Regional Supervisory Council (MPD) no later than 60 days after his death. ${ }^{8}$

There are still families or heirs of the Notary who do not care about the notification and submission of the deceased Notary's protocol. Even though the notification and submission of the Notary protocol to the Notary who has died is very important for the Regional Supervisory Council (MPD) so that they know where the protocol of the Notary who has died is and can appoint/authorize another Notary for the new Notary protocol holder. ${ }^{9}$ Lack of awareness, indifference and ignorance on the part of the Notary's family, heirs of the Notary, or the general public regarding this Notary protocol are the main triggers for obstacles in the submission of the Notary protocol which is an important state archive.

\section{Research Methods}

The research method used in this study is a research method that uses a normative juridical approach. Primary and secondary data sources obtained by interview and literature review (study document). The data that has been collected both from field research and library research were analyzed using descriptive analysis methods.

\section{Results and Discussion}

\subsection{Responsibilities of the Heirs in the Submission of a Notary Protocol that Dies}

Notaries are designated as public officials who have the authority to make authentic deeds, keep the deeds that have been made, guarantee the certainty of the date of making the deed, provide grosse, copies and quotations of the deed. This provision is as stipulated in Article 1 point 1 in conjunction with Article

\footnotetext{
${ }^{7}$ Abdul Ghofur Anshori, (2010), Lembaga Kenotariatan Indonesia Perspektif Hukum dan Etika, Yogyakarta: UII Press, p. 120

8 Ibid.

${ }^{9}$ Sjaifurrachman, dan Habib Adji, (2017), Aspek Pertanggungjawaban Notaris dalam Pembuatan Akta, Bandung: Mandar Maju, p. 236
} 
15 paragraph (1) of Act No. 2 of 2014 Amendments to Act No. 30 of 2004 concerning the Position of a Notary. ${ }^{10}$

The task of a Notary is to control the legal relationship between the parties in a written form and a certain format, so that it is a strong authentic deed in a legal process. ${ }^{11}$ In addition to his authority to make authentic deeds in the sense of "verlijden" (composing, reading out and signing), but also based on Article 16 letter d of Act No. 30 of 2004 in conjunction with Act No. 2 of 2014 concerning the Position of a Notary is mandatory to make it, unless there is a justifiable reason for refusing to make it. ${ }^{12}$

The Notary's own responsibilities when examined from Act No. 30 of 2004 in conjunction with Act No. 2 of 2014 concerning the Position of a Notary are very closely related to the duties and work of a Notary. Thus, apart from making authentic deeds, Notaries are also assigned and responsible for ratifying and registering (legalization and waarmerken) letters/deeds made under the hands of the parties.

The deed made by a Notary authentically describes all stipulations, agreements and actions witnessed by the appearers and witnesses. ${ }^{13}$ In authentic deed contains an agreement between the opposing parties. Notary Public. The conditions for the validity of the agreement according to the law are regulated in Article 1320 of the Civil Code (KUH Perdata). The deed made by a Notary basically has perfect evidentiary power. It is different from the private deed which is made by the interested parties without the help of a public official. ${ }^{14}$

Notaries can be held accountable for authentic deeds which result in null and void. Liability that can burden a Notary is personal responsibility, that is, a Notary is responsible for his own violations. If the authentic deed made before the Notary results in null and void and therefore the appearers feel aggrieved, the Notary is obliged to take responsibility for his actions. A Notary should be careful and careful in making a deed. The definition of responsibility is awareness that

\footnotetext{
${ }^{10}$ Habib Adjie, (2008), Sanksi Perdata dan Administratif Terhadap Notaris Sebagai Pejabat Publik, Bandung: Refika Aditama, p. 27.

${ }^{11}$ Tan Thong Kie, (2000), Studi Notariat, Serba-Serbi Praktek Notariat, Buku I, Jakarta: Ichtiar Baru Van Hoeve, p. 59.

${ }^{12}$ G. H. S. Lumban Tobing, Pengaturan Jabatan Notaris, op.cit. p. 32.

${ }^{13}$ Wawan Tunggal Alam, (2001), Hukum Bicara Kasus-kasus dalam Kehidupan Sehari-hari, Jakarta: Milenia Populer, p. 85.

${ }^{14}$ Taufik Makarao, (2004), Pokok-pokok Hukum Acara Perdata, Jakarta: Rineka Cipta, p. 100
} 
exists within a person in every action. Will have an influence on others as well as for himself. ${ }^{15}$

Apart from the Notary's responsibility, the law itself provides limits regarding the Notary's responsibility so that not all losses are borne by the Notary. Regarding the provisions governing the limits of the Notary's responsibility, it can be seen in Article 65 of the UUJN that the Notary, Substitute Notary, Special Substitute Notary and Temporary Notary Officials are responsible for every deed they make even though the Notary protocol has been submitted or transferred to the Notary protocol keeper.

A Notary Protocol is a collection of documents which are state archives that must be stored and maintained by a Notary, this requires the Notary in storing protocols to act more carefully in storing every protocol submitted to him. Storage of the Notary's protocol in a safe place, which is free from the dangers of theft, fire hazards, humid temperatures, and the dangers of animals that can damage the deed as well as disasters that can cause damage, loss and destruction of documents.

If the Notary does not maintain and maintain the Notary protocol properly, resulting in damage and loss of the Notary protocol, then based on Article 85 of the UUJN, the Notary may be subject to sanctions in the form of an oral warning, written warning, temporary dismissal, respectful dismissal and dishonorable discharge.

Parties who feel aggrieved because of a violation of position or a violation of the code of ethics by a Notary can report the Notary concerned to the Notary Supervisory Council (MPD). A Notary has the obligation to submit a Notary protocol that he keeps after leaving his position. This is as stated in Article 62 of the Amendment UUJN. Regarding the minutes of the deed which are part of the Notary protocol that he keeps, the Notary is responsible for every deed he makes and has the obligation to keep everything related to the deed and other documents he made confidential. The provisions of Article 62 of the UUJN, stipulates that the submission of a Notary protocol is carried out in the case of a Notary:

a. Die. If the Notary dies, the heirs will submit the Notary protocol to another Notary appointed by the Regional Supervisory Council within 30 (thirty) days after the Notary's death. This is as regulated in Article 63 paragraph (3) of the UUJN.

\footnotetext{
${ }^{15}$ Anang Ade Irawan, Pertanggungjawaban Ahli Waris Notaris sebagai Pejabat Umum atas Akta Notaris yang Menimbulkan Kerugian Para Pihak, Jurnal Lentera Hukum, Volume 5 Issue 2 2018, p.350
} 
b. His term of office has ended. If the Notary's term of office has ended, the Notary's protocol submission is carried out by the Notary to another Notary appointed by the Minister on the recommendation of the MPD, as regulated in Article 63 paragraph (4) of the UUJN.

c. Ask yourself or resign. If at the request of the Notary concerned, the Notary protocol shall be submitted by the said Notary to another Notary appointed by the Minister on the recommendation of the MPD, as regulated in Article 63 paragraph (4) of the UUJN.

d. Incapable spiritually and/or physically to carry out the duties of a position as a Notary continuously for more than 3 (three) years. In this case, the submission of the Notary protocol is carried out by a Notary to another Notary appointed by the Minister on the recommendation of the MPD, as stated in Article 63 paragraph (4) of the UUJN.

e. Appointed as a state official. If during his term of office the Notary is appointed as another state official, the Notary protocol from the Notary concerned is submitted to the Notary appointed by the MPD. The Notary holding the Notary protocol from the Notary who is appointed as a state official is authorized to issue a grosse deed, a copy of a deed, or an excerpt of a deed. This is as regulated in Article 64 paragraphs (1) and (2) of the UUJN.

f. Change area of office. If the Notary decides to move his area of office, the Notary protocol is submitted by the Notary to another Notary appointed by the Minister on the recommendation of the MPD, as regulated in Article 63 paragraph (4) of the UUJN.

g. Temporarily suspended. In the event that a Notary is suspended, the Notary protocol is submitted by the Notary to another Notary appointed by the MPD if the temporary suspension is more than 3 (three) months, as regulated in Article 63 paragraph (3) of the UUJN.

h. Dismissed dishonorably. In the event that the Notary is dishonorably dismissed, the submission of the Notary protocol is carried out by the Notary to another Notary appointed by the Minister on the recommendation of the MPD, as regulated in Article 63 paragraph (4) of the UUJN.

The submission of the protocol as referred to in Article 62 of the UUJN is carried out no later than 30 (thirty) days as of making the minutes of protocol submission signed by the Notary who submits and receives the Notary protocol. The Notary holding the Notary Protocol has the authority to issue a grosse deed, a copy of the deed or an excerpt of the deed. If a Notary who receives another Notary protocol receives a protocol that is 25 (twenty five) years old or more, then the protocol must be submitted to the MPD. 
The responsibility of the heirs to the Notary who dies is related to the Notary protocol, namely: ${ }^{16}$

1. Notify the Notary's death to the Notary Supervisory Council (MPD) In principle, every time a Notary dies, based on Article 35 of the UUJN, his family must notify the Notary MPD no later than 7 (seven) working days. In the absence of notification to the Regional Supervisory Council (MPD) regarding the death of the Notary concerned, the Regional Supervisory Council (MPD) finds it difficult to find out who the heirs or families of the Notary are concerned and it is difficult to find out where the whereabouts of the heirs or families of the notary party are. Notary who died.

Basically the Regional Supervisory Council (MPD) does not know the family of the Notary who died because as long as the Notary is still alive and actively working, there is no gathering of information on relatives of the Notary by the Regional Supervisory Council (MPD). There is no information gathering by the Regional Supervisory Council (MPD) regarding this active Notary family information which makes it difficult for the Regional Supervisory Council (MPD) to find relatives and heirs. If the Notary concerned dies. The difficulty in finding the heirs and families of the Notary concerned makes it difficult for the Regional Supervisory Council (MPD) to find out where the Notary protocol of the deceased Notary is.

2. The heirs of a Notary who dies must submit a Notary Protocol to another Notary or the Regional Supervisory Council (MPD).

The administrative responsibility of a Notary is to receive, store, and hold the physical form of each deed which is a Notary Protocol that must be guarded and maintained so that no loss occurs, the Notary protocol ends simultaneously with the end of a Notary's term of office. Thus, the responsibility of a Notary for the deposit of the deed can end, but the responsibility for errors in the making of the deed will never end even though the Notary concerned has ended his term of office. $^{17}$

One of the reasons for the cessation of a person's position as a Notary is because the Notary concerned has died. The death of a Notary causes all his responsibilities to end and the protocols of the Notary concerned must be immediately submitted to the Regional Supervisory Council (MPD) through their heirs to be stored by the Notary who holds the appointed protocol.

In this case, the heirs of the Notary are not only responsible for notifying the MPD but are also responsible for filing the Notary protocol for a period of 30 (thirty) days after the Notary's death. The MPD's authority in this case is not only limited to supervision and guidance, as well as appointing a Notary who receives

\footnotetext{
${ }^{16}$ Ibid.

17 Yofi Permana, Pengaturan Penyerahan Protokol Notaris Yang Telah Meninggal Dunia Dan Prakteknya Di Provinsi Sumatera Barat, Jurnal Cendekia Hukum, August 12 2019, p.5
} 
the Notary Protocol but also provides certainty about the existence and to whom the Notary protocol is submitted up to the time limit set by UUJN.

\subsection{Legal Protection for the Community If the Notary Protocol has not been submitted to another Notary or Recipient of the Notary Protocol}

All actions related to the position of a Notary have been regulated in the UUJN. The UUJN is a form of preventive legal protection given to Notaries, which means legal protection provided by the government before a violation occurs. The provisions contained in the laws and regulations have the aim of preventing a violation, as well as providing limitations in carrying out an authority that is owned and regulating obligations related to it. ${ }^{18}$

Notary who has died, then in this case the heirs of the husband/wife, blood relatives in a straight line of descent from the second marriage are obligated to notify the MPD, the notification is no later than 7 (seven) working days, and the obligation of the Notary's heirs dies in addition to notifying the Assembly Regional Supervisors, the heirs are obliged to submit a Notary protocol. The Notary Protocol must be submitted no later than 30 (thirty) days with the preparation of an official report on the submission of the Notary protocol which is signed by the person submitting and receiving the Notary protocol. This is if the Notary Protocol is not submitted by the heirs, the Regional Supervisory Council shall give a written warning to the heirs and propose a Notary holding the protocol and submit it to the Minister. ${ }^{19}$

If protocol not submitted to the Regional Supervisory Council (MPD) as soon as possible will result in a fatal impact because people who need the Notary protocol may not be served properly by the Regional Supervisory Council (MPD) because the Regional Supervisory Council (MPD) has not received the protocol and there is no Notary protocol holder to the protocol. Then not submitting the Notary protocol to the Regional Supervisory Council (MPD) can result in material losses for people who really need the Notary protocol. ${ }^{20}$

\footnotetext{
${ }^{18}$ Karina Prasetyo Putri, Tanggung Jawab Dan Perlindungan Hukum Bagi Notaris Purna Bakti Terhadap Akta Yang Pernah Dibuat (Analisis Pasal 65 dan Pasal 66 Undang-Undang Nomor 2 Tahun 2014 tentang Perubahan Atas Undang-Undang Nomor 30 Tahun 2004 tentang Jabatan Notaris), Jurnal Fakultas Hukum, Universitas Brawijaya, p. 18

${ }^{19}$ Lentra Nugraha, Pembuatan Salinan Akta Berdasarkan Protokol Werda Notaris Yang Telah Diserahkan Pada Notaris Pemegang Protokol, Thesis of the Faculty of Law, Universitas Indonesia of 2020, p.59

${ }^{20}$ Raisa , Analisis Yuridis Terhadap Penerapan Pasal 35 Undang-Undang Jabatan Notaris Berkaitan Penyerahan Protokol Notaris Yang Telah Meninggal Dunia di Kota Medan, Thesis of Faculty of Law Universitas Sumatera Utara, p.108
} 
Based on the explanation above regarding the consequences if the Notary protocol is not submitted to the MPD, then for the heirs who do not submit the Notary protocol within a period of 30 (thirty) days as referred to in Article 63 paragraph (1) UUJN, then the actions that must be taken by the Supervisory Council The region is taking the Notary protocol because it is the authority of the Regional Supervisory Council, as stipulated in Article 63 paragraph (6) of the UUJN. The pro-active Regional Supervisory Council in taking the Notary protocol from the deceased Notary heirs is none other than because the Notary protocol is a State archive that must be stored and saved. A Notary Protocol as a state archive if it is not immediately submitted to the competent authority, namely the Regional Supervisory Council or a Notary who is appointed as the Protocol Recipient exceeding the period determined by law, it is feared that it could be damaged, or even lost. Taking the Notary protocol that has not been handed over to the heirs is a form of legal protection to the community.

The purpose of storing this Notary protocol is also a form of legal protection to the public. The Notary's own protocol storage place is also arranged in a place that is easily accessible and safe, the storage place must also be lockable. The deeds, reports, etc. must be protected against damage caused by fire and other external influences. Such as humidity and animals that can damage it and also against theft. ${ }^{21}$ The storage can be done in a safe or other place that is safe against fire so that the storage can be likened to deviating other valuable documents. Notary protocol storage as a vital archive and must be stored and maintained properly as an anticipatory measure for conflicts by the parties in the future. $^{22}$

\section{Conclusion}

The responsibility of the heirs in the submission of the protocol of the deceased notary is to notify the notary's death to the Notary Supervisory Council (MPD) no later than 7 (seven) working days. The heirs of a Notary who dies are also required to submit a Notary Protocol to another Notary or the Regional Supervisory Council (MPD). The death of a Notary causes all his responsibilities to end and the protocols of the Notary concerned must be immediately submitted to the Regional Supervisory Council (MPD) through their heirs to be stored by the Notary who holds the protocol that has been appointed. Legal Protection for the Community If the Notary Protocol has not been submitted to another Notary Public or the Recipient of the Notary Protocol, namely based on the above explanation regarding the consequences if the Notary Protocol is not submitted to the MPD, then for the heirs who do not submit the Notary protocol within the 30 (thirty) days as referred to in Article 63 paragraph (1) of the UUJN, the action

${ }^{21}$ Dewi, \& Diradja, (2011), Panduan Teori dan Praktik Notaris, Yogyakarta: Pustaka Yustisia, p. 283

${ }^{22}$ Ali, Z. , (2021), Metode Penelitian Hukum, Jakarta: Sinar Grafika, p.11 
that must be taken by the Regional Supervisory Council is to take the Notary protocol because it is the authority of the Regional Supervisory Council, as stipulated in Article 63 paragraph (6) of the UUJN. The pro-active Regional Supervisory Council in taking the Notary protocol from the deceased Notary heirs is none other than because the Notary protocol is a State archive that must be stored and saved. The Notary Protocol as a state archive if it is not immediately submitted to the competent authority, namely the Regional Supervisory Council or the Notary appointed as the Protocol Recipient exceeding the period determined by law, it is feared that it could be damaged, or even lost. Taking the Notary protocol that has not been handed over to the heirs is a form of legal protection to the community.

\section{References}

Journals:

[1] Anang Ade Irawan, Pertanggungjawaban Ahli Waris Notaris sebagai Pejabat Umum atas Akta Notaris yang Menimbulkan Kerugian Para Pihak, Jurnal Lentera Hukum, Volume 5 Issue 22018

[2] Karina Prasetyo Putri, Tanggung Jawab Dan Perlindungan Hukum Bagi Notaris Purna Bakti Terhadap Akta Yang Pernah Dibuat (Analisis Pasal 65 dan Pasal 66 Undang-Undang Nomor 2 Tahun 2014 tentang Perubahan Atas Undang-Undang Nomor 30 Tahun 2004 tentang Jabatan Notaris), Jurnal Fakultas Hukum, Universitas Brawijaya

[3] Ong Argo Victoria, Ade Riusma Ariyana, Devina Arifani. (2020). Code of Ethics and Position of Notary in Indonesia. Sultan Agung Notary Law $\begin{array}{llll}\text { Review } & 2 & (4), & \text { 397-407, } \quad \text { http://lppm- }\end{array}$ unissula.com/jurnal.unissula.ac.id/index.php/SANLaR/article/view/13536

[4] Raisa, Analisis Yuridis Terhadap Penerapan Pasal 35 Undang-Undang Jabatan Notaris Berkaitan Penyerahan Protokol Notaris Yang Telah Meninggal Dunia di Kota Medan, Thesis of Faculty of Law, Universitas Sumatera Utara

Books:

[1] Abdul Ghofur Anshori. (2010). Lembaga Kenotariatan Indonesia Perspektif Hukum dan Etika. Yogyakarta: UII Press.

[2] Ali Z. (2021). Metode Penelitian Hukum. Jakarta: Sinar Grafika.

[3] Budiono, Herlien. (2013). Dasar Teknik Pembuatan Akta Notaris. Bandung: Citra Aditya Bakti. 
[4] Dewi, \& Diradja. (2011). Panduan Teori dan Praktik Notaris. Yogyakarta: Pustaka Yustisia.

[5] G.H.S Lumban Tobing. (1999). Peraturan Jabatan Notaris, Jakarta: Erlangga.

[6] Habib Adjie. (2009). Sanksi Perdata dan Administratif terhadap Notaris sebagai Pejabat Publik. Bandung: Refika Aditama.

[7] Habib Adjie. (2014). Hukum Notaris Indonesia Tafsir Telematik Terhadap UU No 30 Tahun 2004 Tentang Jabatan Notaris, Surabaya: Refika Aditama.

[8] Indra Iswara. (2020). Profesi Notaris dan PPAT ditinjau dari Perspektif Hukum Islam. Kediri: Maktabah Muslim Sunni

[9] Lentra Nugraha, Pembuatan Salinan Akta Berdasarkan Protokol Werda Notaris Yang Telah Diserahkan Pada Notaris Pemegang Protokol, ThesisFaculty of Law, Universitas Indonesia of 2020

[10] Sjaifurrachman, dan Habib Adji. (2017). Aspek Pertanggungjawaban Notaris dalam Pembuatan Akta, Bandung: Mandar Maju.

[11] Soegondo Notodisoerjo. (1993), Hukum Notariat di Indonesia Suatu Penjelasan. Second Edition. Jakarta: Raja Grafindo.

[12] Tan Thong Kie. (2000). Studi Notariat, Serba-Serbi Praktek Notariat. Buku I. Jakarta: Ichtiar Baru Van Hoeve.

[13] Taufik Makarao. (2004). Pokok-pokok Hukum Acara Perdata. Jakarta: Rineka Cipta.

[14] Wawan Tunggal Alam. (2001). Hukum Bicara Kasus-kasus dalam Kehidupan Sehari-hari. Jakarta: Milenia Populer.

[15] Zainuddin Ali. (2010). Pelaksanaan Hukum Waris Di Indonesia. Jakarta: Sinar Grafika.

Regulation:

[1] Act No. 2 of 2014 concerning Amendments to Act No. 30 of 2004 concerning Notary Positions 
[2] Decree of the Minister of Law and Human Rights of the Republic of Indonesia Number M.39-PW.07.10 of 2004 